MATEC Web of Conferences 6, 07004 (2013)

DOI: $10.1051 /$ matecconf/20130607004

(C) Owned by the authors, published by EDP Sciences, 2013

\title{
Compressive strength at high temperatures of a concrete made with recycled tire textile and steel fibers
}

\author{
Cristina Calmeiro Santos ${ }^{1}$ and João Paulo C. Rodrigues ${ }^{2}$ \\ ${ }^{1}$ ISISE, Polytechnic Institute of Castelo Branco, Portugal \\ ${ }^{2}$ ISISE, University of Coimbra, Portugal
}

\begin{abstract}
This paper presents the results of a research work on the evaluation of the compressive strength at high temperatures of a concrete made with recycled tire steel and textile fibers. It was considered five different concrete compositions, with a water/cement ratio $(\mathrm{W} / \mathrm{C}=0.43)$, differ only in the type and amount of fibers. The compositions with smaller amounts of textile fibers were those that gave better results. The compositions with steel fibers showed a less explosive rupture showing the effectiveness of this type of fibers in the spalling and cracking control.
\end{abstract}

\section{INTRODUCTION}

The studies carried out by different authors have shown that the strength of the concrete, even the normal, degrades with increasing temperature [1-4]. These reductions on the mechanical properties are however more pronounced for high strength concretes. The high strength concretes are also more susceptible to spalling than the normal ones due to their higher compactness and the existence of pores of smaller diameter that difficult the release of the water vapour generated inside the concrete in case of fire [5-7]. On the other hand the addition of ultrafine particles in the cements used in these compositions and even the adjuvants make the concrete compact and with pores closed to the point of creating difficulties of the water vapour realising to outside [8].

Bazant and Kaplan also noted that the fact the coefficients of thermal expansion of aggregates and cement paste are not equal, leads to thermal differential movements between them, which translate into micro-cracks and spalling on the concrete matrix [9].

Khoury has developed important studies in this area studying the mechanical properties of concrete at high temperatures. The author found that the mixing proportions of aggregates with cement and water has a major impact on mechanical properties of concrete with temperature because usually important chemical and physical changes occur, with losing of cohesion, that lead to its degradation [10].

Bayramov et al conducted a study to optimize the amount of steel fibers on high strength concrete to achieve higher ductility and increase its energy absorption capacity. The steel fibers used in the compositions presented a relation length/diameter between 55 and 80 . The authors studied the effect of distribution of fibers in the concrete composition because they thought to have influence. The results showed that the diameter and orientation of steel fibers had an important role in the compressive strength of concrete. The steel fibers have been introduced with the aim of strengthening the concrete, reducing cracking and spalling [11].

Lau and Anson carried out a study to characterize the mechanical properties of normal and high performance concretes subjected to different temperatures. They also studied the effect of add $1 \%$ of steel fibers as reinforcement for both types of concrete. In this study the authors found that as higher is the increasing rate of temperature lower is the permeability of concrete and higher the risk of spalling

This is an Open Access article distributed under the terms of the Creative Commons Attribution License 2.0, which permits unrestricted use, distribution, and reproduction in any medium, provided the original work is properly cited. 


\section{MATEC Web of Conferences}

of the concrete. The addition of steel fibers improves the performance of concrete in fire regardless the mixture and maximum temperature reached. Thus, the authors found that the addition of steel fibers in the concrete improves its compressive strength [12].

Çavdar studied the effect of four different types of fibers on the concrete compressive strength at high temperatures. The fibers tested were polypropylene (PP), carbon (CF), glass (GF) and polyvinyl alcohol (PVA). The amounts used were $0.0 \%, 0.5 \%, 1.0 \%, 1.5 \%$ and $2.0 \%$ in volume, and the temperatures tested were $20,100,450$ and $650^{\circ} \mathrm{C}[13]$.

Çavdar found that with the increasing of temperature the cement matrix change in a way that at $450{ }^{\circ} \mathrm{C}$ damages and some cracking and at $650{ }^{\circ} \mathrm{C}$ extensive cracking and deterioration of concrete occur, respectively. He has also concluded that the compressive strength decreases with the temperature, being the value for the mixtures with PP and GF fibers about $40-50 \%$ at $450{ }^{\circ} \mathrm{C}$ and $55-70 \%$ at $650{ }^{\circ} \mathrm{C}$ of the resistance at ambient temperature. The mixtures with $\mathrm{CF}$ and with PVA fibres reduce about 3-8\% at $450{ }^{\circ} \mathrm{C}$ and $50-60 \%$ at $650{ }^{\circ} \mathrm{C}$ of the compressive strength at ambient temperature. The reduction in compressive strength is lower when the amount of CF fibres added to the mixture is between 0.5 and $1.5 \%$ in volume for any temperature in study [13].

Bangi and Horiguchi studied the influence of the length, diameter and fiber type in reducing the internal water vapor pressure of the high strength concretes subjected to high temperatures. In this study were tested polypropylene (PP), polyvinyl alcohol (PVA) and steel fibers (FA). All compositions were reinforced with the same amount of fibers $(0.1 \%$ by volume $)$ and subjected to a heating rate of $10^{\circ} \mathrm{C} / \mathrm{min}$ [14].

The authors observed a significant reduction in the pressure of the concrete mixture regardless the type of fibre used and its geometry. They also found that the longer fibers with smaller diameters attenuate the increase of pressure at the mixture pores when compared with the shorter fibers with larger diameters and regardless of the type of fibre. On the other hand, found that concrete mixtures reinforced with PP fibers had a better behavior under fire conditions than the PVA fibers, because PP fibers have better bonding properties with the concrete matrix [14].

The authors also found that the addition of steel and PP fibers reduce the cracking and spalling, respectively, since the last ones will sublimate for temperatures of around $170{ }^{\circ} \mathrm{C}$, creating a net of micro-channels from which the water vapour can be released to outside and with this reduce the internal pressure at mixture pores. The experimental results showed that the addition of fibers with lower sublimation temperatures presented and improved the concrete performance when compared to fibers with higher melting temperatures [14].

It is in this context and in view of the increasing need to manage natural resources rationally [15-18], that appears this research, which aims to evaluate experimentally the compressive strength at room and the high temperatures of the concrete made with recycled tire steel and textile fibers. This research aims not only to study the problem of spalling in concrete as the use of steel and textile fibres from recycled tires in your control.

\section{EXPERIMENTAL STUDY}

\subsection{Concrete composition}

The following components were used: Portland cement CEM II/A-L 42.5R, superplasticizer SikamentHE 200P (SP), coarse aggregates $(12.7 \mathrm{~mm}$ size) $(\mathrm{CC})$ and sand $(<4 \mathrm{~mm}$ size) (FS).

The five concrete compositions in study differed only in the type and amount of fibers in the mixtures. In the first composition, plain concrete (RC), there were no fibers. In the second and third composition were incorporated textile fibers (TF) (fig. 1a) replacing the larger gravel limestone aggregates in the amount of 2 (TF1) and 4 (TF2) $\mathrm{kg} / \mathrm{m}^{3}$, respectively. In the fourth and fifth composition were used steel fibres (FA) (fig. 1b) replacing the larger gravel limestone aggregates in the amount of 30 (FA1) and 70 (FA2) $\mathrm{kg} / \mathrm{m}^{3}$, respectively. The steel and textile fibers were recycled from tires. 
IWCS 2013
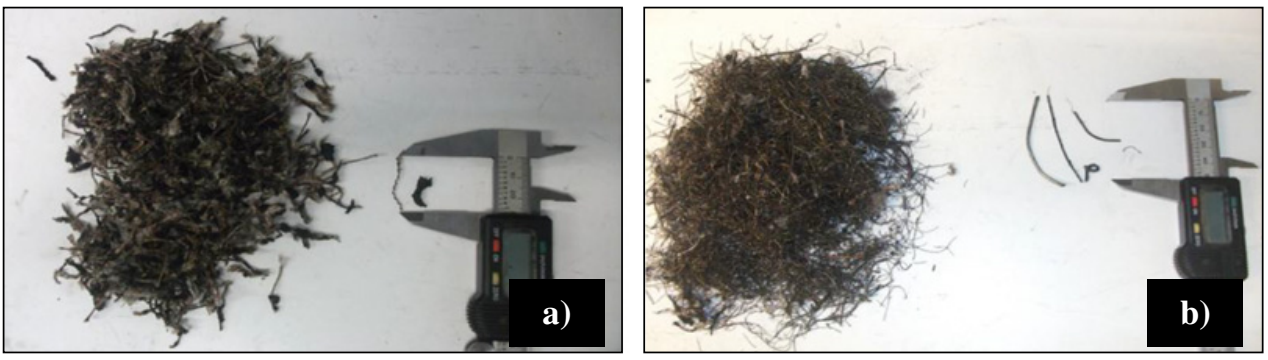

Figure 1. Recycled fibers from tires. a) Textiles fibers. b) Steel fibers.

Table 1. Concrete compositions per $\mathrm{m}^{3}$.

\begin{tabular}{llllllll}
\hline & CEM & FS & CC & W & W/C & TF & SF \\
& {$\left[\mathrm{kg} / \mathrm{m}^{3}\right]$} & {$\left[\mathrm{kg} / \mathrm{m}^{3}\right]$} & {$\left[\mathrm{kg} / \mathrm{m}^{3}\right]$} & {$\left[1 / \mathrm{m}^{3}\right]$} & & {$\left[\mathrm{kg} / \mathrm{m}^{3}\right]$} & {$\left[\mathrm{kg} / \mathrm{m}^{3}\right]$} \\
\hline RC & 400 & 698 & 1097 & 173 & 0.43 & - & - \\
TF1 & 400 & 698 & 1095 & 173 & 0.43 & 2 & - \\
TF2 & 400 & 698 & 1093 & 173 & 0.43 & 4 & - \\
SF1 & 400 & 698 & 1067 & 173 & 0.43 & - & 30 \\
SF2 & 400 & 698 & 1027 & 173 & 0.43 & - & 70 \\
\hline
\end{tabular}

Table 2. Compression strength and resistance class of tested concretes.

\begin{tabular}{lll}
\hline Concrete type & $f_{\text {cm }}(\mathrm{MPa})$ & Resistance class \\
\hline RC & 46.44 & $\mathrm{C} 35 / 45$ \\
TF1 & 49.11 & $\mathrm{C} 35 / 45$ \\
TF2 & 46.62 & $\mathrm{C} 35 / 45$ \\
SF1 & 50.63 & $\mathrm{C} 35 / 45$ \\
SF2 & 45.14 & $\mathrm{C} 30 / 37$ \\
\hline
\end{tabular}

It is decided to replace the larger aggregate for both types of fibers for different reasons: the textile fibers in order to allow the realizing of the water vapor in the concrete in case of fire and avoid the spalling and the steel fibers in order to resist the thermal stresses generated due to the heating.

The concrete compositions are reported in Table 1.

In Table 2 are presented the compression strength and resistance class of the concretes according to EN 206-1 (2007) [19].

The specimens were cured, during 28 days, in a room with a vapour saturated environment (relative humidity $>98 \%$ ) and temperature of $20^{\circ} \mathrm{C}$. After this they were removed and left in the lab ambient temperature (between 18 and $20^{\circ} \mathrm{C}$ ) and humidity (between 40 and 50\%) waiting for testing. The specimens were tested at least with three months of age.

\subsection{Specimens}

The assessment of the compressive strength of concrete was carried out on cylindrical specimens of $75 \mathrm{~mm}$ diameter and $225 \mathrm{~mm}$ height, that corresponded to a height/diameter ratio of $3: 1$. The specimens were provided with five type $\mathrm{K}$ thermocouples in order to register the temperatures inside the concrete. The location of thermocouples in the specimens was based on the recommendations of RILEM TC 200 HTC [20] (Fig. 2). 

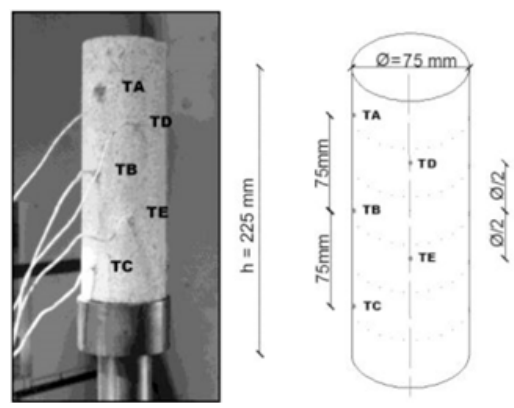

Figure 2. Specimens and location of thermocouples.

Table 3. Test Plan.

\begin{tabular}{llll}
\hline Test & $\begin{array}{l}\text { Specimen dimensions } \\
(\mathrm{mm})\end{array}$ & Loading level & $\begin{array}{l}\text { Temperature } \\
\left({ }^{\circ} \mathrm{C}\right)\end{array}$ \\
\hline compressive strength & cylinders, $\mathrm{d}=75: h=200$ & $0.5 \mathrm{f}_{\mathrm{cd}}$ & $20,300,500,700$ \\
\hline
\end{tabular}

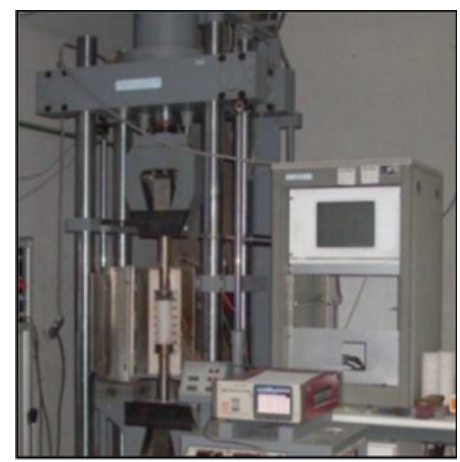

Figure 3. Test-setup.

\subsection{Test plan}

The characteristics of the specimens are summarized in Table 3. Three tests as a minimum were developed for each combination of parameters.

\subsection{Test set-up and procedure}

The experimental set-up for the compression strength tests were composed by a universal tensile/compression machine of $600 \mathrm{kN}$, an electric tubular oven and a data acquisition system (Fig. 3).

The specimens were subjected, during the entire test, to a constant compressive loading equal to a percentage of the design value of the compression strength of the concrete at ambient temperature $\left(0.5 \mathrm{f}_{\mathrm{cd}}\right)$. This load tried to simulate the conditions when concrete is in a real compressed structural element.

The specimens were heated up at a rate of $3{ }^{\circ} \mathrm{C} / \mathrm{min}$ up to the desired level of temperature. The temperature was considered achieved when the average temperatures on the three superficial thermocouples match the temperature of the oven. The maximum axial temperature differences between the three superficial temperature readings could not exceed $1^{\circ} \mathrm{C}$ at $20^{\circ} \mathrm{C}, 5^{\circ} \mathrm{C}$ at $100^{\circ} \mathrm{C}$ and $20^{\circ} \mathrm{C}$ 


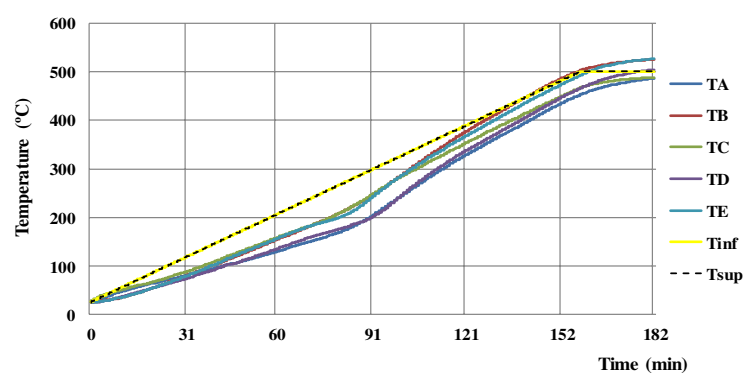

Figure 4. Temperature evolution in the cross-section of a $\mathrm{SF} 1$ specimen $-500^{\circ} \mathrm{C}$ series.

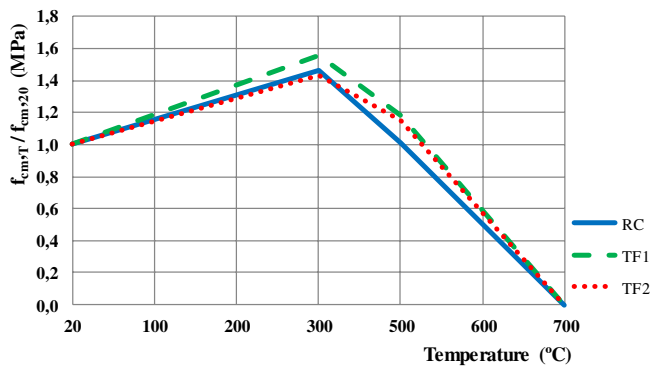

Figure 5. Compressive strength with temperature (RC, TF1 and TF2 concretes).

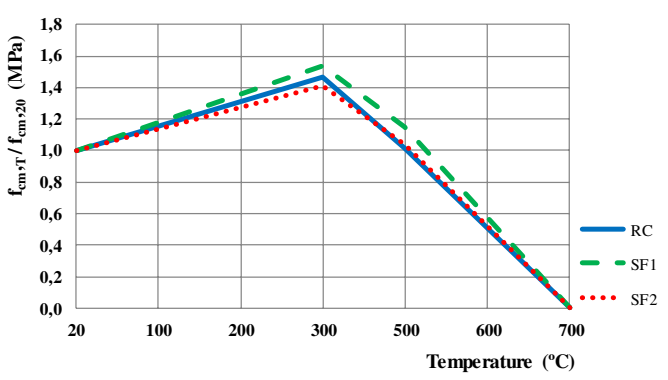

Figure 6. Compressive strength with temperature (RC, SF1 and SF2 concretes).

at $700^{\circ} \mathrm{C}$. The specimens were then kept at that temperature for an hour to stabilize. After this the compressive tests were carried out.

The test procedure was adopted according to RILEM TC 200 HTC recommendations [20]. The loading was increased in the compressive test at a loading rate of $0.25 \mathrm{kN} / \mathrm{s}$ up to rupture of the specimen.

\section{RESULTS}

\subsection{Temperature distribution}

Figure 4 presents, as an example, the evolution of temperature in the cross-section of a concrete specimen with $30 \mathrm{~kg} / \mathrm{m}^{3}$ of steel fibres (SF1) for the $50{ }^{\circ} \mathrm{C}$ test series. The analysis of the figure shows that temperature inside the oven was kept uniform during testing, since the temperature curves of the two zones of the oven were nearly coincident throughout the test. This resulted in a good thermal exposure that the specimen has been subjected in the oven and that remained in the different tests.

In Figure 4 it can be also seen a good temperature uniformity inside the specimen during the heating and temperature stabilization phase (60 minutes). However there is a slight delay in the concrete mass heating in the specimen up to about $120 \mathrm{~min}$.

\subsection{Compressive strength}

The results obtained in the experimental tests for the compressive strength are summarized in Table 4 and Figures 5 and 6. In Table 4 are still presented the average and standard deviation of the values.

Figure 5 shows the variation with temperature of the compressive strength of the concretes with $2 \mathrm{~kg} / \mathrm{m}^{3}$ (TF1) and $4 \mathrm{~kg} / \mathrm{m}^{3}$ (TF2) of textile fibers, related to its value at room temperature. The values are compared to the ones of the plain concrete (RC). The results presented for $300^{\circ} \mathrm{C}$ show an increase on the compressive strength of around $47 \%$ for the RC, $56 \%$ for the TF1, and $43 \%$ for the TF2. For 
MATEC Web of Conferences

Table 4. Results of compressive strength of the tested concretes.

\begin{tabular}{|c|c|c|c|c|c|}
\hline $\begin{array}{l}\text { Concrete } \\
\text { composition }\end{array}$ & Temperature $\left({ }^{\circ} \mathrm{C}\right)$ & $\begin{array}{l}f_{c, T} \\
(\mathrm{MPa})\end{array}$ & $\begin{array}{l}f_{c m, T} \\
(\mathrm{MPa})\end{array}$ & $\sigma_{x}$ & $\frac{f_{c m, T}}{f_{c} m}$ \\
\hline \multirow{8}{*}{$\mathrm{RC}$} & 20 & & 30.25 & & \\
\hline & & 44.36 & & & \\
\hline & 300 & 42.44 & 44.36 & 1.92 & 1.47 \\
\hline & & 46.27 & & & \\
\hline & & 29.70 & & & \\
\hline & 500 & 30.20 & 30.62 & 1.18 & 1.01 \\
\hline & & 31.95 & & & \\
\hline & 700 & - & (a) & - & 0.00 \\
\hline \multirow{8}{*}{ TF1 } & 20 & & 26.23 & & \\
\hline & & 42.02 & & & \\
\hline & 300 & 38.30 & 40.92 & 2.28 & 1.56 \\
\hline & 42.45 & & & & \\
\hline & & 29.60 & & & \\
\hline & 500 & 31.64 & 30.94 & 1.16 & 1.18 \\
\hline & & 31.58 & & & \\
\hline & 700 & - & (a) & - & 0.00 \\
\hline \multirow{8}{*}{ TF2 } & 20 & & 26.29 & & \\
\hline & & 35.27 & & & \\
\hline & 300 & 39.74 & 37.58 & 2.24 & 1.43 \\
\hline & & 37.72 & & & \\
\hline & & 29.60 & & & \\
\hline & 500 & 29.65 & 30.25 & 1.08 & 1.15 \\
\hline & & 31.49 & & & \\
\hline & 700 & - & (a) & - & 0.00 \\
\hline \multirow{8}{*}{ SF1 } & 20 & & 30.18 & & \\
\hline & & 45.10 & & & \\
\hline & 300 & 46.13 & 46.35 & 1.38 & 1.54 \\
\hline & 47.83 & & & & \\
\hline & & 34.82 & & & \\
\hline & 500 & 33.84 & 34.64 & 0.73 & 1.15 \\
\hline & & 35.27 & & & \\
\hline & 700 & - & (a) & - & 0.00 \\
\hline \multirow{8}{*}{ SF2 } & 20 & & & 31.61 & \\
\hline & & 42.60 & & & \\
\hline & 300 & 43.23 & 44.57 & 2.89 & 1.41 \\
\hline & & 47.89 & & & \\
\hline & & 31.71 & & & \\
\hline & 500 & 33.79 & 32.83 & 1.05 & 1.04 \\
\hline & & 33.00 & & & \\
\hline & 700 & - & (a) & - & 0.00 \\
\hline
\end{tabular}

$500{ }^{\circ} \mathrm{C}$ the $\mathrm{RC}$ presented strength similar to the one at ambient temperature and the others still present strength of $20 \%$ higher than the one at ambient temperature. For $700{ }^{\circ} \mathrm{C}$ all the specimens have suffered rupture before reaching this temperature, making it impossible to be tested at compression. 
IWCS 2013

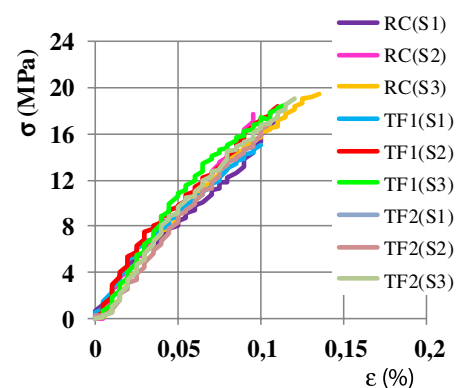

Figure 7. Stress-strain curves $-0.5 \mathrm{f}_{\mathrm{cd}}$ and $500{ }^{\circ} \mathrm{C}-$ (RC, TF1 and TF2 concretes).

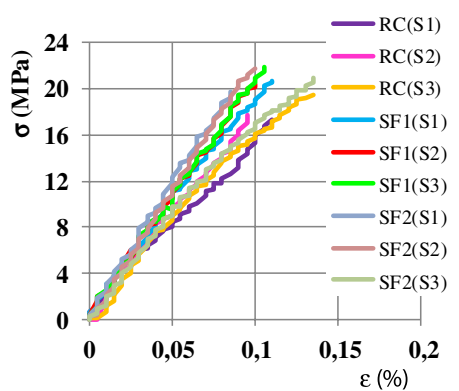

Figure 8. Stress-strain curves $-0.5 \mathrm{f}_{\mathrm{cd}}$ and $500{ }^{\circ} \mathrm{C}-$ (RC, SF1 and SF2 concretes).
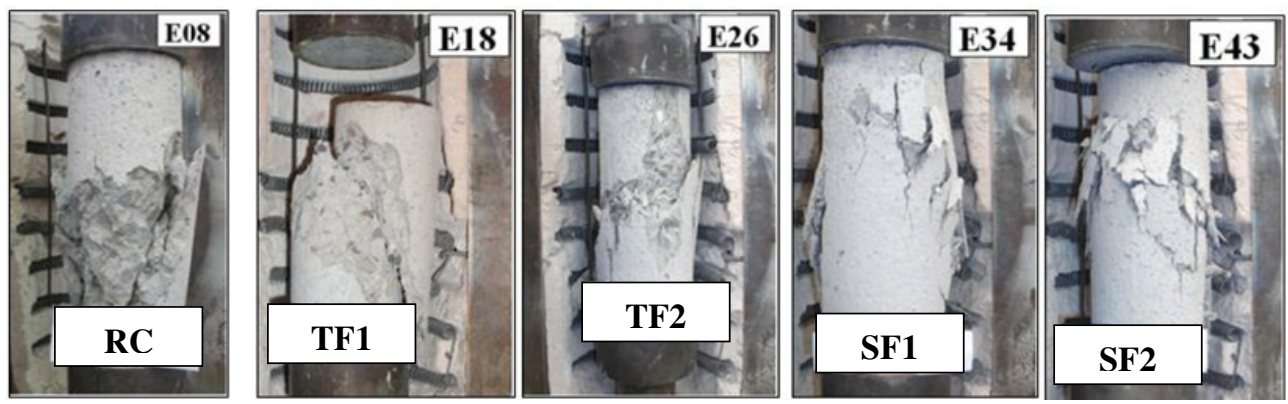

Figure 9. Specimens after the compressive strength tests $-500^{\circ} \mathrm{C}$ series.

Concerning to Figure 6, it shows the variation with temperature of the compressive strength of the concrete with $30 \mathrm{~kg} / \mathrm{m}^{3}$ (SF1) and $70 \mathrm{~kg} / \mathrm{m}^{3}$ (SF2) of steel fibers, related to its value at room temperature. The values are also compared to the ones of the plain concrete (RC). The addition of steel fibers to the concrete also resulted in an increasing of the compressive strength for different temperature levels up to $500{ }^{\circ} \mathrm{C}$. At $300{ }^{\circ} \mathrm{C}$ there was an increase of the compressive strength of about $47 \%$ for the RC, $54 \%$ for the SF1 and $41 \%$ for the SF2 concrete. At $500^{\circ} \mathrm{C}$ the compressive strength of the RC and SF2 concretes are similar to the one at ambient temperature and for the SF1 is $15 \%$ higher than the one at ambient temperature. Once more the strength was null at $700{ }^{\circ} \mathrm{C}$. The results showed that an addition of $30 \mathrm{~kg} / \mathrm{m}^{3}$ of steel fibers to the concrete presented a better result in terms of the compressive strength than an addition of $70 \mathrm{~kg} / \mathrm{m}^{3}$.

Figures 7 and 8 present the stress-strain curves registered in the compressive strength tests, for the three specimens tested, for each type of concrete, for the $500{ }^{\circ} \mathrm{C}$ test series.

Figure 9 presents, as an example, photos of the specimens after the compressive strength tests for the $500{ }^{\circ} \mathrm{C}$ test series. Higher amounts of fibers seam leading to greater destruction on the specimens.

\section{CONCLUSIONS}

The following conclusions may be drawn from the present study:

- The concrete compositions with textile or steel fibers presented, for temperatures between 300 and $500^{\circ} \mathrm{C}$, values of the compressive strength higher than the ones at ambient temperature;

- For temperatures, between 300 and $500^{\circ} \mathrm{C}$, the smaller amount of steel fibres in concrete, gave better results in terms of compressive strength of concrete. The steel fibres, when not excessive, have a 


\section{MATEC Web of Conferences}

beneficial effect on the compressive strength of concrete. These fibers improve the behavior of the concrete because they resist to the thermal stresses generated during heating that degrades the concrete reducing the compressive strength;

- A quite similar result was observed for the compositions with textile fibres;

- The concretes with steel fibers presented a smooth rupture when comparing to plain concrete, attesting the effectiveness of this type of fiber in concrete ductile and cracking control.

- The textile and steel fibres from recycled tires showed to be a good solution in concrete composition to control cracking and spalling and can be a good substitute for the commercial steel and polypropylene fibers.

\section{References}

[1] Ghan Y.N., Peng G.F., Anson M., Residual strength and pore structure of high-strength concrete and normal strength concrete after exposure to high temperatures, Cement and Concrete Composites, 21(1), 23-27, 1999.

[2] Schneider U, Behavior of concrete at high temperatures, Beuth Verlag, Berlin, 122, 1982.

[3] Phan L.T., Carino N.J., Review of mechanical properties of HSC at elevated temperature, Journal of Materials in Civil Engineering, 10(1), 58-64, 1998.

[4] Smith L.M., The assessment of fire damage to concrete structure, $\mathrm{PhD}$ thesis, Paisley College of Technology, 490, 1983.

[5] Castillo C., Durrani A.J., Effect of transient high temperature on high-strength concrete. ACI Materials Journal, 87(1), 47-53, 1990.

[6] Jahren P.A., Fire resistance of high strength/dense concrete with particular references to the use of condensed silica fume - a review, In Proceedings of the Third International Conference, Fly Ash, Silica Fume, Slag, and Natural Pozzolans in Concrete, AC1 SP-114, Detroit, USA, 1013-1049, 1989.

[7] Hager I., Comportement à haute température des bétons de haute performance - évolution des principales propriétés mécaniques, $\mathrm{PhD}$ thesis, Ecole Nat. des Ponts et Chaussées, France, 183, 2004.

[8] Aitcin P.C., The durability characteristics of high performance concrete: a review, Cement and Concrete Composites, 25(4-5), 409-420, 2003.

[9] Bazant P.Z., Kaplan M.F., Concrete at high temperatures, Material, properties and mathematical models, Longman, Harlow, England, 412, 1996.

[10] Khoury G.A., Effect of fire on concrete and concrete structures, Progress in Structural Engineering and Materials, 2(4), 429-447, 2000.

[11] Bayramov F., Tasdemir C., Tasdemir M.A., Optimisation of steel fibre reinforced concretes by means of statistical response surface method, Cement and Concrete Composites, 26(6), 665-675, 2004.

[12] Lau A., Anson M., Effect of high temperatures on high performance steel fibre reinforced concrete, Cement and Concrete Research, 36(9), 1698-1707, 2006.

[13] Çavdar A., A study on the effects of high temperature on mechanical properties of fiber reinforced cementitious composites, Composites Part B, 43(5), 2452-2463, 2012.

[14] Bangi M.R., Horiguchi T., Effect of fibre type and geometry on maximum pore pressures in fibrereinforced high strength concrete at elevated temperatures, Cement and Concrete Research, 42(2), 459-466, 2012.

[15] Olivares F.H., Barluenga G., Fire performance of recycled rubber-filled high-strength concrete, Cement and Concrete Research, 34, 109-117, 2004.

[16] Khaloo A.R., Dehestani M., Rahmatabadi P., Mechanical properties of concrete containing a high volume of tire - rubber particles, Waste Management Journal, 28(12), 2472-2482, 2008. 
[17] Turki M., Bretagne E., Rouis M.J., Quéneudec M., Microstructure, physical and mechanical properties of mortar - rubber aggregates mixtures, Construction and Building Materials, 23(7), 2715-2722, 2009.

[18] Gesoğlu M., Gúneyisi E., Permeability properties of self-compacting rubberized concretes, Construction and Building Materials, 25(8), 3319-3326, 2011.

[19] NP EN 206-1, Concrete Part 1: Specification, performance, production and conformity, 84, 2007.

[20] RILEM TC - 200 HTC, Mechanical Concrete Properties at High Temperature - Modelling and Applications, Materials and Structures, 38(284), 913-919, 2005. 